\title{
PERSSERESSI
}

Volume 2/Nomor1

Juli - Desember 2019

E-ISSN 2656-050X

\section{KONTROVERSI VIDEO LAST HOPE KITCHEN EPISODE PUDING BABI KURMA DI YOUTUBE (ANALISIS UNSUR SARA SEMIOTIKA CHARLES SANDERS PIERCE)}

\author{
Murwanti Fajar Yani, Rini Riyantini \\ Program Studi Ilmu Komunikasi UPN Veteran Jakarta \\ murwanti.fajar@gmail.com, rinihoriyantini@gmail.com
}

\begin{abstract}
Last Hope Kitchen video episode of Dates Pig Pudding which is displayed on YouTube channel of Tretan Muslim with viewers of more than 275 thousand raises controversy because it is considered to contain elements of SARA. The controversy can be seen from the conversations and gestures shown by Muslims and Coki such as "Pork mixed with palm juice, the pig becomes halal or the dates become unclean?". The purpose of this research was to interpretation elements of SARA in Last Hope Kitchen video episode of Dates Pig Pudding. This research uses discourse theory, public space, critical discourse analysis, and semiotics. The method used is qualitative with Charles Sanders Pierce's semiotic analysis technique, videos are analyzed based on semiotic trichotomy, namely signs, objects, and interpretations. The results of this research are signs of conversation and gesture, objects in the form of symbols shown in the video produce meaning that Muslims and Coki display dark comedy genre videos that are still very rarely displayed in Indonesia and contain elements of SARA. Comedy content that carries the element of religion in it is very sensitive for the people of Indonesia.
\end{abstract}

Keywords: Last Hope Kitchen Video, Controversy, SARA, Dark Comedy, Semiotics.

\section{A. Pendahuluan}

Video Last Hope Kitchen adalah video dari channel YouTube Tretan Universe milik Tretan Muslim yang merupakan seorang komika Indonesia. Tretan Muslim merupakan komika dari Stand Up Comedy Indonesia Season 3 di Kompas TV. Saat ini Muslim bersama dengan salah satu temannya Coki Pardede, dikenal sebagai salah satu pendiri channel komedi Majelis Lucu Indonesia yang merupakan channel komedi populer dikalangan masyarakat. Komedi dengan konten memasak yang mencampurkan berbagai macam bahan yang tidak umum digunakan untuk memasak.

Dalam video Last Hope Kitchen episode Puding Babi Kurma menghadirkan bintang tamu spesial yang saat ini sangat populer di kalangan para pecinta Stand Up Comedy yaitu Coki Pardede yang juga merupakan salah satu penggagas Majelis Lucu Indonesia. Dalam video ini, seperti biasa mereka memasak dengan menggunakan bahanbahan masakan yang tidak umum yaitu puding babi kurma. Dimana daging babi dimasak dengan menggunakan air sari kurma. Video tersebut meraih viewers lebih dari 


\section{PERSEEPSSI}

Volume 2/Nomor1

Juli - Desember 2019

E-ISSN 2656-050X

275 ribu dibandingkan dengan video episode lainnya yang hanya mampu menembus angka 100 ribu viewers.

Dengan pembawaan yang lucu disertai gesture kedua komika ini, video berdurasi lebih dari 20 menit tersebut menimbulkan reaksi berupa komentar dari penontonnya di YouTube. Seperti yang masyarakat ketahui kedua bahan masakan tersebut merupakan bahan makanan yang salah satunya diharamkan dalam agama Islam. Sedangkan video tersebut mencampurkan antara makanan yang diharamkan dengan buah kurma yang dikenal sebagai salah satu buah yang banyak tumbuh di negeri Arab dan banyak dikonsumsi oleh orang beragama Islam.

Video tersebut menghasilkan kontroversi diberbagai kalangan masyarakat dan tergolong ke dalam genre dark comedy. Karena Muslim dan Coki dalam penyampaian di videonya seolah-olah saling menertawakan bahan-bahan makanan tersebut yang menjadi simbol dari agamanya masing-masing. Contohnya adalah kata-kata yang maksudnya bercanda seperti "Daging babi dicampur dengan sari kurma, babinya jadi halal atau kurmanya yang jadi haram?" dianggap sensitif bagi beberapa pihak dan menghasilkan komentar dari penontonnya.

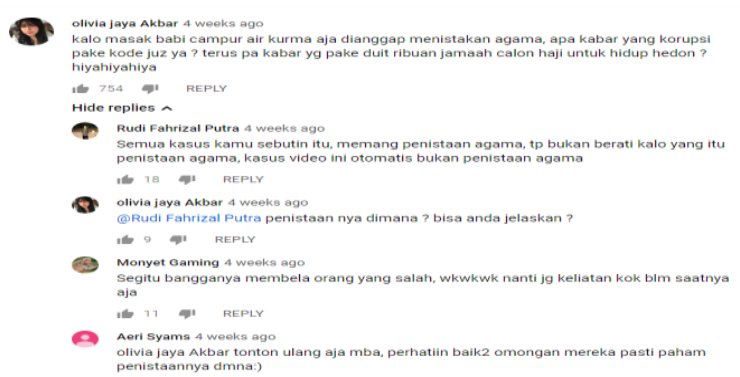

Sumber: YouTube.com

\section{Gambar 1. Komentar viewers video Last Hope Kitchen episode Puding Babi Kurma}

Fokus dari penelitian ini adalah analisis semiotika dengan tingkatan trikotomi yang melihat unsur SARA berdasarkan tanda, objek, dan interpretant dalam video Last Hope Kitchen episode Puding Babi Kurma di YouTube. Sementara tujuan dari penelitian ini adalah untuk mengetahui representasi pada video yang berunsur SARA dalam tayangan Last Hope Kitchen episode Puding Babi Kurma di YouTube. 


\section{PERSSERPSI}

Volume 2/Nomor1

Juli - Desember 2019

E-ISSN 2656-050X

Pendekatan penelitian yang digunakan adalah kualitatif yang mengeksplorasi pemaknaan pesan dari video Last Hope Kitchen episode Puding Babi Kurma dengan menggunakan teknik analisis data semiotika Charles Sanders Pierce yaitu tanda, objek, dan interpretant. Dengan teknik pengumpulan data berupa studi dokumentasi, penulis memilih 9 dari 15 scene yang terdiri dari 24 gambar dalam video yang mengandung unsur SARA. Penelitian ini menggunakan teknik keabsahan data untuk memvalidasi hasil analisis dengan membandingkan sumber data yang dianalisis dalam video tersebut. Misalnya antara gambar dan narasi, antara narasi dan ekspresi, atau antara ekspresi dengan gesture.

Proses penyampaian pesan melalui media mengalami pergeseran penting. Jika media selama ini merupakan pusat informasi, dan informasi itu diberikan atau dipublikasikan dengan satu arah, kini media menjadi lebih interaktif. Khalayak tidak lagi sekedar objek yang terpapar oleh informasi, tetapi khalayak telah dilibatkan lebih aktif karena teknologi menyebabkan interaksi di media bisa terjadi (Nasrullah, 2014, hlm 12).

Seperti halnya komedi yang saat ini bisa disampaikan melalui media dimana khalayak tidak hanya sekedar menjadi penonton melainkan bisa ikut memberikan kritik dan saran terhadap pesan yang disampaikan. Perkembangan media komunikasi ini membuat salah satu komedian yaitu Tretan Muslim ikut mengembangkan komedinya berupa audio visual melalui media online. Dimana penontonnya juga berperan untuk kesuksesan pesan yang akan disampaikan.

Media baru sangat beragam dan tidak mudah didefinisikan. Fokus perhatian terutama pada aktivitas kolektif terutama pada penggunaan publik, seperti berita daring, iklan, aplikasi penyiaran (termasuk mengunduh musik dan lain-lain), forum dan aktivitas diskusi, World Wide Web (WWW), pencarian informasi dan potensi pembentukan komunitas tertentu (McQuail, 2012: 148).

Penggunaan media sosial saat ini sangat melesat maju di kalangan masyarakat. Siapa pun dapat menyampaikan pesan melalui akun media sosial yang dimilikinya kepada khalayak. Tretan Muslim memanfaatkan media sosial sebagai sarana berkomedi seperti twitter, instagram, serta youtube. Para pengikutnya berasal dari berbagai 


\section{PERSERES SI}

Volume 2/Nomor1

Juli - Desember 2019

E-ISSN 2656-050X

kalangan masyarakat baik itu pecinta Stand Up Comedy maupun khalayak umum yang juga bisa melihat komedi yang ditampilkan oleh Tretan Muslim.

YouTube dalam situs resminya menjelaskan bahwa mereka memberikan kebebasan berekspresi karena setiap orang memiliki kebebasan untuk berbicara, menyampaikan pendapat, mengadakan dialog terbuka, dan kebebasan berkreasi dapat menghasilkan suara, format, dan kemungkinan baru. YouTube memiliki kebijakan dan keamanan bagi para penggunanya, antara lain (1) konten sensual atau ketelanjangan, (2) konten yang merugikan atau berbahaya, (3) konten yang mengandung kebencian, serta (4) pelecehan dan cyberbullying (YouTube.com, diakses pada tanggal 7 November 2018).

YouTube menjadi salah satu pilihan media sosial yang digunakan Tretan Muslim saat ini karena melihat antusiasme khalayak yang lebih sering menonton YouTube dibandingkan dengan televisi. Komedi yang disampaikan melalui YouTube terlihat sangat bebas sehingga penontonnya bisa menikmati komedi tanpa sensor tidak seperti pada tayangan di televisi. Karena YouTube juga mengandalkan kebebasan berekspresi untuk para penggunanya dengan tetap memerhartikan syarat dan ketentuan yang berlaku.

YouTube sangat berkaitan dengan konten atau tema dari video yang dibuat. Wehype.id menyampaikan enam dasar dalam membuat konten di channel YouTube, yaitu: (1) shareable, (2) komunikatif dan interaktif, (3) konsistensi, (4) targeted, (5) mudah ditemukan, (6) kolaborasi (Wehype.id, diakses pada tanggal 9 November 2018).

Tretan Muslim menciptakan konten yang sesuai dengan kemampuannya yaitu konten komedi. Salah satunya bergenre dark comedy. Dark comedy mengajak penonton untuk menghadapi persoalan yang dihindari, termasuk hal sensitif seperti agama. Tetapi genre ini memang tidak untuk semua orang. Beberapa contoh dari dark comedy adalah serial kartun South Park, film Three Billboards Outside Ebbing, Missouri tahun 2017 arahan Martin McDonagh, serta yang terbaru adalah tayangan YouTube babi kurma oleh Tretan Muslim dan Coki Pardede (Tirto.id, diakses pada tanggal 31 Oktober 2018).

Genre ini dibawakan oleh Muslim sebagai salah satu tanda toleransi beragama antara dirinya dengan temannya Coki Pardede. Dimana mereka melontarkan kata-kata dan menampilkan gesture yang seolah-olah mengejek satu sama lain. Dengan 46

Program Studi Ilmu Komunikasi FISIPUPN Veteran Jakarta 


\section{PERSERES SI}

Volume 2/Nomor1

Juli - Desember 2019

E-ISSN 2656-050X

beragamnya penonton yang berasal dari berbagai kalangan membuat video yang ditampilkan oleh Muslim tersebut menimbulkan kontroversi berupa reaksi komentar yang kebanyakan mengatasnamakan agama mereka.

Di Indonesia dalam kerusuhan sosial bernuansa SARA (Suku, Agama, Ras, Antargolongan) sudah banyak terjadi. SARA sangat identik dengan konflik, perselisihan, kekerasan, diskriminasi, dan sebagainya (Kholifah, 2014, hlm 138).

Video Last Hope Kitchen episode puding babi kurma dianggap mengandung unsur SARA menurut masyarakat yang menonton video tersebut. Karena di dalam video tersebut Muslim dan Coki mencampurkan bahan makanan yang keduanya mencerminkan agama yang berbeda. Dimana kurma identik dengan pemeluk agama Islam, sedangkan babi diharamkan dalam ajaran tersebut.

Penulis menggunakan beberapa teori dalam penelitian ini, antara lain diskursus, ruang publik, critical discourse analysis, dan semiotika. Diskursus adalah bentuk refleksi tindakan komunikatif. Maksudnya, diskursus adalah kelanjutan tindakan komunikatif dengan memakai sarana lain yaitu sarana argumentatif. Dapat dikatakan bahwa diskursus menandai suatu bentuk komunikasi modern dimana orang tidak begitu saja menerima sesuatu dengan pemahaman-pemahaman yang berkembang melalui tradisi, melainkan menguji hal tersebut dengan pertimbangan rasional (Hardiman, 2009, hlm 25-37).

Kontroversi yang terjadi karena video tersebut menimbulkan diskursus di kalangan masyarakat. Banyak diantara mereka memberikan argumentasi dan kritiknya melalui komentar di channel YouTube Tretan Universe. Komika lain juga ikut mengomentari video tersebut di media sosial yang mereka miliki seperti twitter dan instagram. Para penonton memberikan argumen mereka masing-masing terkait video yang dinilai mengandung unsur SARA tersebut. Timbulnya reaksi kritik dan argumentasi memicu beberapa YouTuber memberikan reaksi terhadap video tersebut. Bahkan kontroversi ini tidak hanya terjadi di YouTube saja melainkan media sosial lain sehingga masyarakat yang sebelumnya tidak tahu mengenai video tersebut akhirnya menonton dan ikut berkomentar.

Ruang publik merupakan sarana warga berkomunikasi, berdiskusi, berargumen, dan menyatakan sikap terhadap suatu problematika (Hardiman, 2009, hlm 11). Ruang 47 


\section{PERSERESPI}

Volume 2/Nomor1

Juli - Desember 2019

E-ISSN 2656-050X

publik bukanlah sekedar 'tempat fisik', melainkan diskursus atau komunikasi warga itu sendiri yang mereproduksi ruang diantara mereka.

Dalam hal ini media sosial khususnya YouTube menjadi ruang publik bagi para penonton video Last Hope Kitchen episode puding babi kurma yang menyampaikan komentar berupa kritik dan argumennya. Mereka berasal dari berbagai kalangan dengan berbeda-beda suku, agama, dan ras. Tetapi mereka merasa perlu untuk hadir di ruang publik untuk mencari tahu realitas yang sebenarnya terjadi. Dengan menyampaikan berbagai macam pendapatnya, penonton tersebut tidak merasa takut terjadi pembatasan sehingga komentar-komentar yang mereka sampaikan pun terkadang sudah terlewat batas bahkan bisa saling menyinggung satu sama lain. Ruang publik disini dapat berguna sebagai ruang untuk melihat realitas sosial yang sedang terjadi dalam hal ini kontroversi dari video Last Hope Kitchen episode puding babi kurma.

Critical discourse analysis bertujuan untuk menggali secara sistematis dari hubungan yang kabur antara praktek, teks, peristiwa diskursif dengan struktur relasi dan proses sosial budaya yang lebih luas. Pemilihan teori ini sangat cocok dalam penelitian yang dilakukan oleh penulis karena dilihat dari bidang perhatiannya yaitu bagaimana Tretan Muslim menampilkan video di media sosial YouTube yang dinilai bertentangan dengan budaya masyarakat karena dianggap mengandung unsur SARA dari kata-kata dan bahasa yang digunakan dalam proses penyampaiannya. Dengan menggunakan teori critical discourse analysis, penulis akan menggambarkan dan menganalisis bagaimana suatu kritik dari kehidupan sosial yang tercermin melalui teks lisan maupun tulisan dalam sebuah media.

Dalam penelitian ini, penulis menggunakan teori semiotika Charles Sanders Pierce karena akan menganalisa video Last Hope Kitchen episode Puding Babi Kurma dengan melihat tanda-tanda yang terlihat dari setiap gambar di dalam video tersebut. Setelah itu, penulis akan menganalisa objek yang terlihat pada setiap scenenya. Dimana akhir dari analisisnya adalah mengetahui makna yang terkandung dari gabungan antara tanda dan objek yang terdapat dari setiap scene dalam video Last Hope Kitchen episode Puding Babi Kurma. Setelah menganalisa tanda, objek, dan makna, maka dapat diketahui 
hasil dari analisis tersebut yang selanjutnya akan dibahas dan disimpulkan sehingga penelitian ini dapat diselesaikan.

\section{B. Hasil dan Pembahasan}

Hasil analisis semiotika dari video Last Hope Kitchen episode Puding Babi Kurma yang dianalisis berdasarkan fokus penelitian yang mengandung unsur SARA terdiri atas 9 scene dengan 24 gambar. Tayangan video tersebut mengandung gambar, setting, dan dialog yang dideskripsikan berdasarkan semiotika Charles Sanders Peirce meliputi sign, object, dan interpretant dengan rincian seperti pada tabel.

\section{Tabel 1. Hasil analisis scene 1}

\begin{tabular}{|c|c|c|c|}
\hline Gambar & Sign & Object & Interpretant \\
\hline \multirow[t]{3}{*}{ Gambar } & $\begin{array}{l}\text { Qualisign } \\
\text { Muslim dan Coki berada di } \\
\text { sebuah rooftop pada malam } \\
\text { hari dan saling } \\
\text { berdampingan dimana Coki } \\
\text { menggunakan kaos dengan } \\
\text { tulisan "Anti Religion- } \\
\text { Religion Club". }\end{array}$ & $\begin{array}{l}\text { Ikon } \\
\text { Muslim memakai topi } \\
\text { berwarna kuning berada } \\
\text { di sebelah kiri menunjuk } \\
\text { Coki sementara Coki } \\
\text { memakai kacamata } \\
\text { berada di sebelah kanan. }\end{array}$ & $\begin{array}{l}\text { Rheme } \\
\text { Muslim yang memakai topi } \\
\text { berwarna kuning di } \\
\text { sebelah kiri menunjuk } \\
\text { Coki di sebelah kanan yang } \\
\text { memakai kacamata untuk } \\
\text { memperkenalkannya. }\end{array}$ \\
\hline & $\begin{array}{l}\text { Sinsign } \\
\text { Muslim dan Coki } \\
\text { memperkenalkan diri } \\
\text { mereka. }\end{array}$ & $\begin{array}{l}\text { Indeks } \\
\text { Muslim dan Coki akan } \\
\text { berperan sebagai chef. }\end{array}$ & $\begin{array}{l}\text { Dicent } \\
\text { Coki adalah bintang tamu } \\
\text { dalam video ini. }\end{array}$ \\
\hline & $\begin{array}{l}\text { Legisign } \\
\text { Muslim dan Coki merupakan } \\
\text { pemeran dalam video. }\end{array}$ & $\begin{array}{l}\text { Simbol } \\
\text { Muslim menunjuk Coki } \\
\text { sebagai simbol } \\
\text { memperkenalkan. Tulisan } \\
\text { "Anti Religion-Religion } \\
\text { Club" sebagai simbol tidak } \\
\text { beragama. }\end{array}$ & $\begin{array}{l}\text { Argument } \\
\text { Muslim dan Coki adalah } \\
\text { pemeran dalam video ini } \\
\text { bertindak sebagai chef. } \\
\text { Coki menggunakan kaos } \\
\text { dengan tulisan "Anti } \\
\text { Religion-Religion Club" } \\
\text { karena tidak } \\
\text { mementingkan agama. } \\
\text { Muslim adalah seorang } \\
\text { umat Islam sementara } \\
\text { Coki adalah seorang yang } \\
\text { non Islam. }\end{array}$ \\
\hline Gambar & $\begin{array}{l}\text { Qualisign } \\
\text { Muslim dan Coki } \\
\text { memperlihatkan daging babi. } \\
\text { Coki "Ini namanya daging } \\
\text { babi. Kalau yang sebelah sini } \\
\text { gak ada bedanya ya sama } \\
\text { daging sapi." } \\
\text { Muslim "Yang membuat } \\
\text { sangat babi apa?" } \\
\text { Coki "Ini yang ini. Terus ini }\end{array}$ & $\begin{array}{l}\text { Ikon } \\
\text { Coki memegang daging } \\
\text { babi yang diletakkan di } \\
\text { sebuah tempat. Dan } \\
\text { tempat untuk menjemur } \\
\text { pakaian yang digunakan } \\
\text { sebagai alas. }\end{array}$ & $\begin{array}{l}\text { Rheme } \\
\text { Muslim dan Coki yang } \\
\text { memperlihatkan daging } \\
\text { babi di sebuah tempat } \\
\text { dengan alasnya adalah } \\
\text { tempat untuk menjemur } \\
\text { pakaian. }\end{array}$ \\
\hline
\end{tabular}




\begin{tabular}{|c|c|c|c|}
\hline & $\begin{array}{l}\text { ada, babi tuh ada beberapa } \\
\text { lapisnya. Gini-gini lah } \\
\text { pokoknya intinya." }\end{array}$ & & \\
\hline & $\begin{array}{l}\text { Sinsign } \\
\text { Daging babi adalah bahan } \\
\text { yang akan dimasak. }\end{array}$ & $\begin{array}{l}\text { Indeks } \\
\text { Muslim dan Coki akan } \\
\text { memasak daging babi } \\
\text { dengan alat-alat yang } \\
\text { seadanya. }\end{array}$ & $\begin{array}{l}\text { Dicent } \\
\text { Muslim dan Coki akan } \\
\text { memasak daging babi } \\
\text { dengan alas penjemur } \\
\text { pakaian. }\end{array}$ \\
\hline & $\begin{array}{l}\text { Legisign } \\
\text { Daging babi tidak dimakan } \\
\text { oleh semua orang. }\end{array}$ & $\begin{array}{l}\text { Simbol } \\
\text { Daging babi sebagai } \\
\text { simbol makanan yang } \\
\text { haram bagi umat Islam. }\end{array}$ & $\begin{array}{l}\text { Argument } \\
\text { Bahan utama dari } \\
\text { masakan ini adalah daging } \\
\text { babi yang tidak bisa } \\
\text { dimakan oleh semua orang } \\
\text { karena diharamkan bagi } \\
\text { umat Islam. }\end{array}$ \\
\hline \multirow[t]{3}{*}{ Gambar 4.3} & $\begin{array}{l}\text { Qualisign } \\
\text { Muslim "Coba kita } \\
\text { dengarkan. Neraka neraka! } \\
\text { Ampun, neraka! Babi ini } \\
\text { neraka." }\end{array}$ & $\begin{array}{l}\text { Ikon } \\
\text { Muslim yang } \\
\text { mendekatkan daging babi } \\
\text { ke telinganya dan raut } \\
\text { wajah mereka yang } \\
\text { sedang tertawa. }\end{array}$ & $\begin{array}{l}\text { Rheme } \\
\text { Muslim yang seolah-olah } \\
\text { sedang mendengar suara } \\
\text { dari daging babi yang } \\
\text { didekatkan ke telinganya } \\
\text { dan Coki tertawa di } \\
\text { sebelahnya. }\end{array}$ \\
\hline & $\begin{array}{l}\text { Sinsign } \\
\text { Muslim dan Coki tertawa } \\
\text { ketika mengatakan Neraka. }\end{array}$ & $\begin{array}{l}\text { Indeks } \\
\text { Muslim membuat daging } \\
\text { babi sebagai bahan } \\
\text { tertawaan dengan Coki } \\
\text { yang menyebut Neraka. }\end{array}$ & $\begin{array}{l}\text { Dicent } \\
\text { Daging babi tidak dapat } \\
\text { mengeluarkan suara tetapi } \\
\text { Muslim yang membuat } \\
\text { seolah-olah daging babi itu } \\
\text { bersuara. }\end{array}$ \\
\hline & $\begin{array}{l}\text { Legisign } \\
\text { Muslim mendekatkan daging } \\
\text { babi ke telinganya seolah- } \\
\text { olah mendengar suara. }\end{array}$ & $\begin{array}{l}\text { Simbol } \\
\text { Mendekatkan daging babi } \\
\text { ke telinga sebagai simbol } \\
\text { mendengar. Muslim dan } \\
\text { Coki tertawa sebagai } \\
\text { simbol rasa senang. }\end{array}$ & $\begin{array}{l}\text { Argument } \\
\text { Muslim menyebut Neraka } \\
\text { karena Neraka adalah } \\
\text { tempat bagi orang-orang } \\
\text { yang melanggar perintah } \\
\text { Allah seperti misalnya } \\
\text { umat Islam yang memakan } \\
\text { daging babi. }\end{array}$ \\
\hline \multirow[t]{3}{*}{ Gambar 4.4} & $\begin{array}{l}\text { Qualisign } \\
\text { Coki "Masa sih? Iya bro, ada } \\
\text { sayup-sayup suara jeritan } \\
\text { kafir kafir!” }\end{array}$ & $\begin{array}{l}\text { Ikon } \\
\text { Coki yang mendekatkan } \\
\text { daging babi ke telinganya } \\
\text { dan raut wajah mereka } \\
\text { yang sedang tertawa. }\end{array}$ & $\begin{array}{l}\text { Rheme } \\
\text { Coki yang seolah-olah } \\
\text { mendengar suara dari } \\
\text { daging babi yang } \\
\text { didekatkan ke telinganya } \\
\text { dan mereka berdua } \\
\text { tertawa. }\end{array}$ \\
\hline & $\begin{array}{l}\text { Sinsign } \\
\text { Coki dan Muslim tertawa } \\
\text { ketika mengatakan Kafir. }\end{array}$ & $\begin{array}{l}\text { Indeks } \\
\text { Coki membuat daging babi } \\
\text { sebagai bahan tertawaan } \\
\text { dengan Muslim yang } \\
\text { menyebut Kafir. }\end{array}$ & $\begin{array}{l}\text { Dicent } \\
\text { Daging babi tidak dapat } \\
\text { mengeluarkan suara tetapi } \\
\text { Coki yang membuat } \\
\text { seolah-olah daging babi itu } \\
\text { bersuara. }\end{array}$ \\
\hline & $\begin{array}{l}\text { Legisign } \\
\text { Coki mendekatkan daging } \\
\text { babi ke telinganya seolah- } \\
\text { olah mendengar suara. }\end{array}$ & $\begin{array}{l}\text { Simbol } \\
\text { Mendekatkan daging babi } \\
\text { ke telinga sebagai simbol } \\
\text { mendengar. Muslim dan } \\
\text { Coki tertawa sebagai } \\
\text { simbol rasa senang. }\end{array}$ & $\begin{array}{l}\text { Argument } \\
\text { Coki menyebut Kafir } \\
\text { karena Kafir adalah orang- } \\
\text { orang yang menyembah } \\
\text { selain Allah. Daging babi } \\
\text { adalah makanan yang } \\
\end{array}$ \\
\hline
\end{tabular}




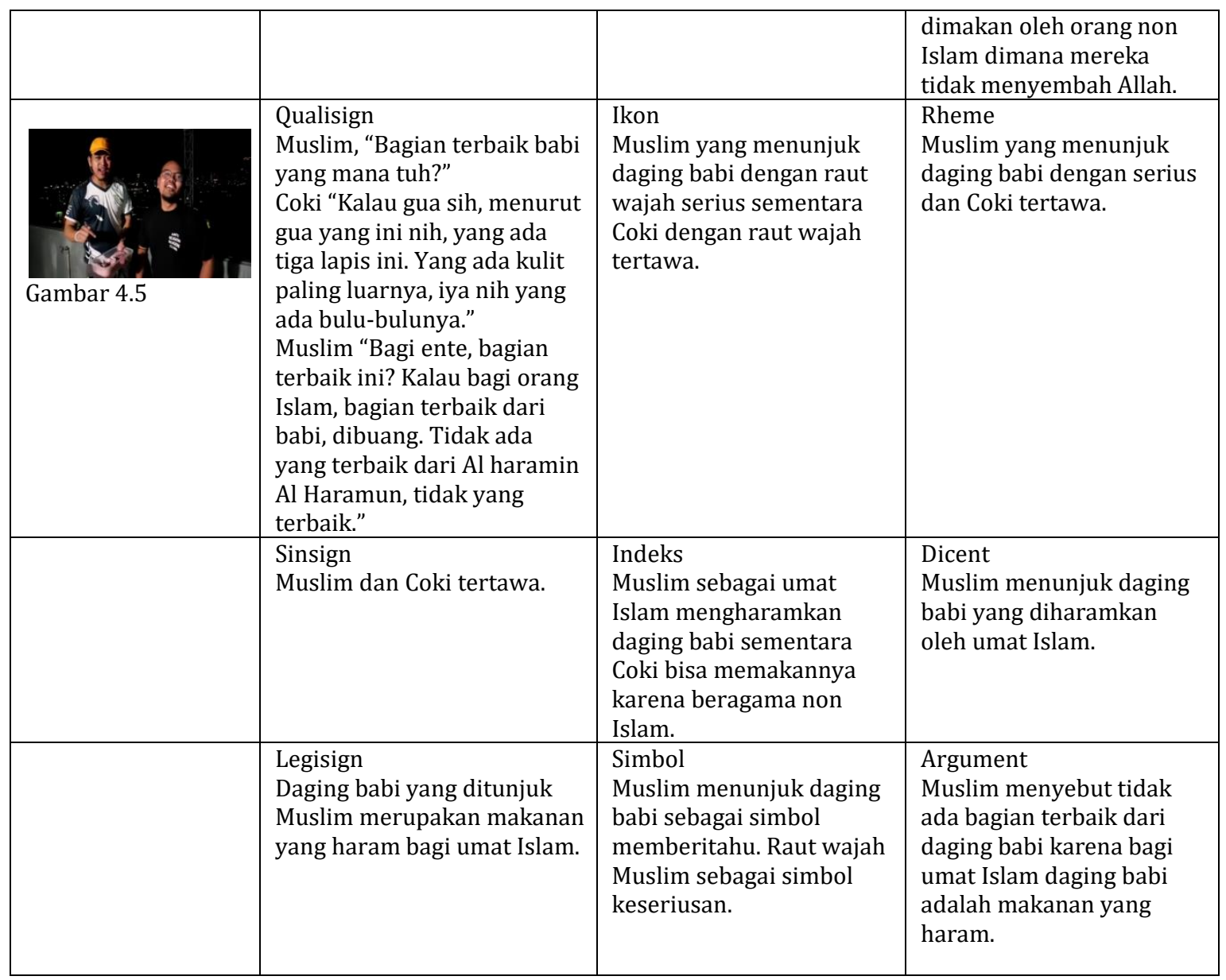

Tabel 2. Hasil analisis scene 2

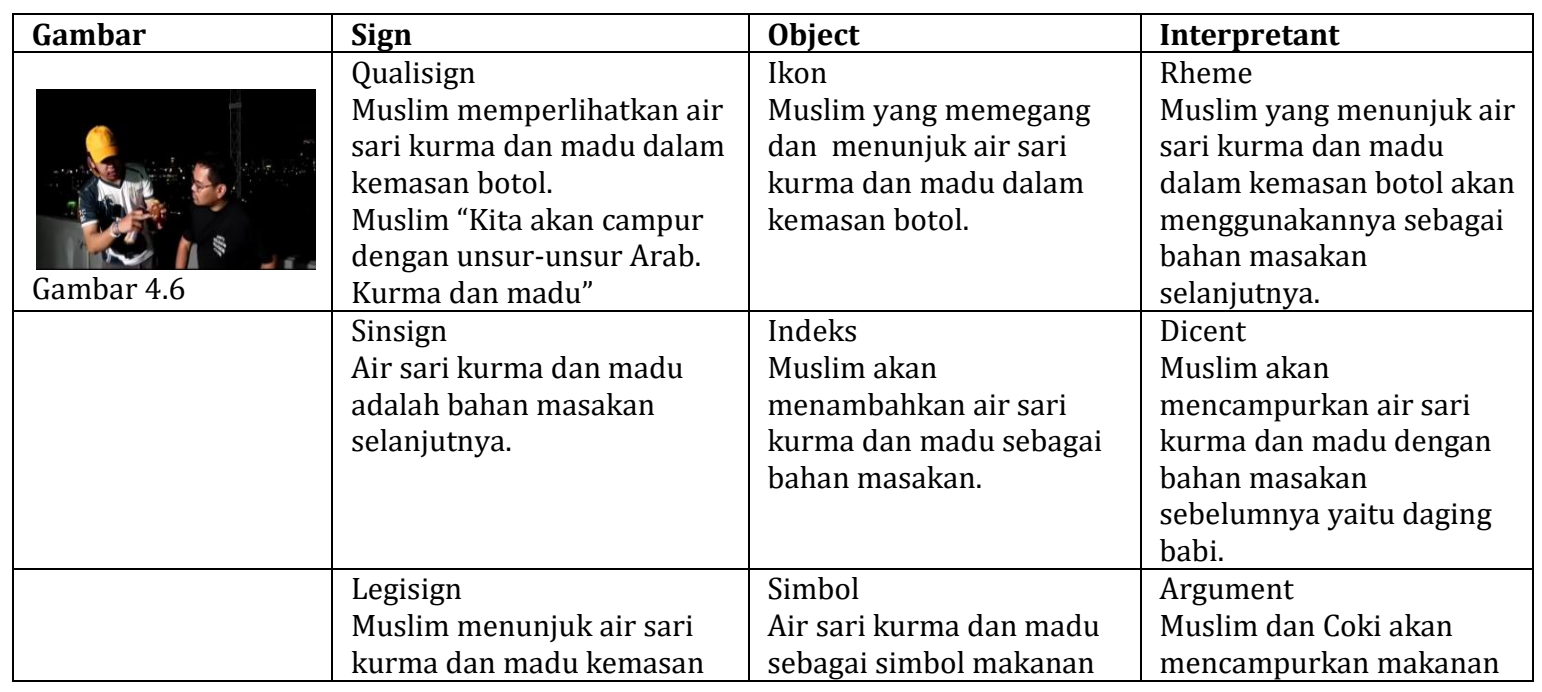




\begin{tabular}{|c|c|c|c|}
\hline & $\begin{array}{l}\text { botol yang memiliki logo } \\
\text { halal. }\end{array}$ & halal. & $\begin{array}{l}\text { yang halal dengan } \\
\text { makanan yang haram. }\end{array}$ \\
\hline Gambar 4.7 & $\begin{array}{l}\text { Qualisign } \\
\text { Muslim “Kira-kira apa yang } \\
\text { terjadi kalau makanan } \\
\text { haram, al babi ini, dicampur } \\
\text { dengan makanan barokah, al } \\
\text { kurma dan madu." }\end{array}$ & $\begin{array}{l}\text { Ikon } \\
\text { Muslim yang memegang } \\
\text { air sari kurma dan madu } \\
\text { dalam kemasan botol, Coki } \\
\text { melihat ke arahnya dan } \\
\text { dengan raut wajah } \\
\text { tertawa. }\end{array}$ & $\begin{array}{l}\text { Rheme } \\
\text { Muslim yang menyebut air } \\
\text { sari kurma dan madu } \\
\text { sebagai makanan barokah } \\
\text { dengan wajah yang serius } \\
\text { sementara Coki yang } \\
\text { melihatnya tertawa. }\end{array}$ \\
\hline & $\begin{array}{l}\text { Sinsign } \\
\text { Muslim menunjukkan } \\
\text { ekspresi serius ketika } \\
\text { mengatakan makanan } \\
\text { barokah. }\end{array}$ & $\begin{array}{l}\text { Indeks } \\
\text { Muslim menyebut air sari } \\
\text { kurma dan madu sebagai } \\
\text { makanan barokah karena } \\
\text { merupakan makanan yang } \\
\text { halal. }\end{array}$ & $\begin{array}{l}\text { Dicent } \\
\text { Air sari kurma dan madu } \\
\text { merupakan makanan yang } \\
\text { bisa dimakan umat Islam } \\
\text { karena halal. }\end{array}$ \\
\hline & $\begin{array}{l}\text { Legisign } \\
\text { Air sari kurma dan madu } \\
\text { termasuk makanan yang } \\
\text { halal dan diperbolehkan } \\
\text { dalam agama Islam. }\end{array}$ & $\begin{array}{l}\text { Simbol } \\
\text { Makanan halal sebagai } \\
\text { simbol makanan yang } \\
\text { barokah. }\end{array}$ & $\begin{array}{l}\text { Argument } \\
\text { Air sari kurma dan madu } \\
\text { merupakan makanan yang } \\
\text { barokah karena halal dan } \\
\text { biasa dikonsumsi oleh } \\
\text { siapapun khususnya umat } \\
\text { Islam. }\end{array}$ \\
\hline Gambar 4.8 & $\begin{array}{l}\text { Qualisign } \\
\text { Coki “Ini al kurma, al madu, } \\
\text { al babi al haram, al kafir." }\end{array}$ & $\begin{array}{l}\text { Ikon } \\
\text { Muslim yang memegang } \\
\text { air sari kurma dan madu } \\
\text { dalam kemasan botol. } \\
\text { Serta Coki yang menunjuk } \\
\text { dirinya sendiri. Raut } \\
\text { wajah keduanya tertawa. }\end{array}$ & $\begin{array}{l}\text { Rheme } \\
\text { Muslim yang akan } \\
\text { menambahkan air sari } \\
\text { kurma dan madu sebagai } \\
\text { bahan masakan yang halal, } \\
\text { sementara Coki tertawa } \\
\text { saat menunjuk dirinya } \\
\text { sendiri sebagai Al kafir. }\end{array}$ \\
\hline & $\begin{array}{l}\text { Sinsign } \\
\text { Coki tertawa ketika } \\
\text { mengatakan Al kafir. }\end{array}$ & $\begin{array}{l}\text { Indeks } \\
\text { Coki menunjuk dirinya } \\
\text { sendiri saat berkata Al } \\
\text { Kafir karena dia beragama } \\
\text { non Islam. }\end{array}$ & $\begin{array}{l}\text { Dicent } \\
\text { Coki adalah orang yang } \\
\text { beragama non Islam yang } \\
\text { menyembah selain Allah. }\end{array}$ \\
\hline & $\begin{array}{l}\text { Legisign } \\
\text { Coki menunjuk dirinya } \\
\text { sendiri ketika mengatakan } \\
\text { Al kafir. }\end{array}$ & $\begin{array}{l}\text { Simbol } \\
\text { Coki menunjuk dirinya } \\
\text { sendiri saat menyebut Al } \\
\text { kafir sebagai simbol } \\
\text { pengakuan. }\end{array}$ & $\begin{array}{l}\text { Argument } \\
\text { Coki menganggap bahwa } \\
\text { dirinya Kafir dengan } \\
\text { menunjuk dirinya sendiri } \\
\text { karena beragama non } \\
\text { Islam yang menyembah } \\
\text { selain Allah. } \\
\end{array}$ \\
\hline
\end{tabular}

Tabel 3. Hasil analisis scene 3

\begin{tabular}{|l|l|l|l|}
\hline Gambar & Sign & Object & Interpretant \\
\hline & Qualisign & Ikon & Rheme \\
& Coki kesulitan memotong & Muslim memegang air sari & Coki dengan serius \\
& daging babi. & kurma dalam kemasan & memotong daging babi \\
& Coki "Daging babi keras & botol. Sementara Coki & sebelum dimasak \\
& kalau dipotong." & memotong daging babi & menggunakan pisau dan \\
\hline
\end{tabular}




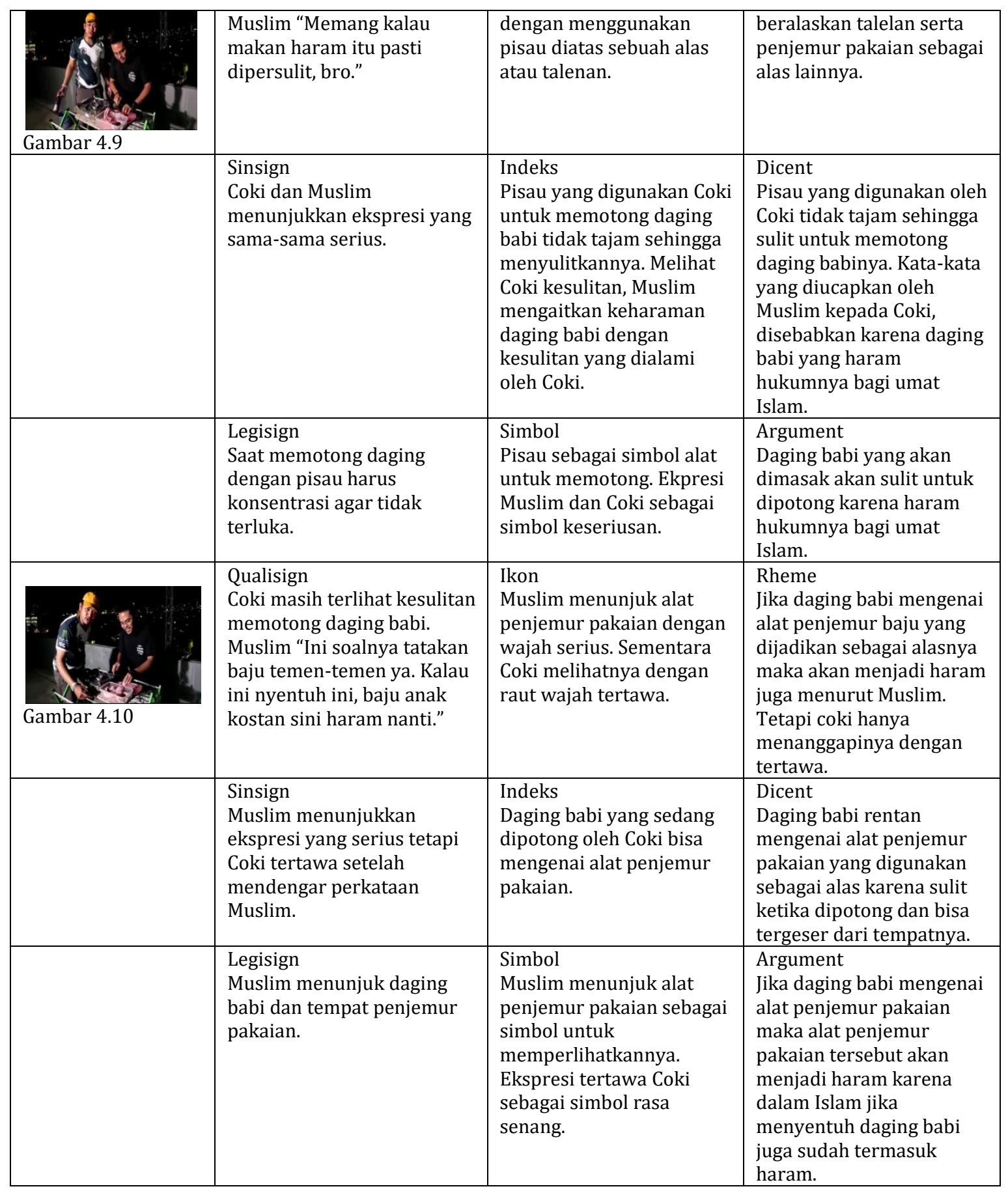


Tabel 4. Hasil analisis scene 4

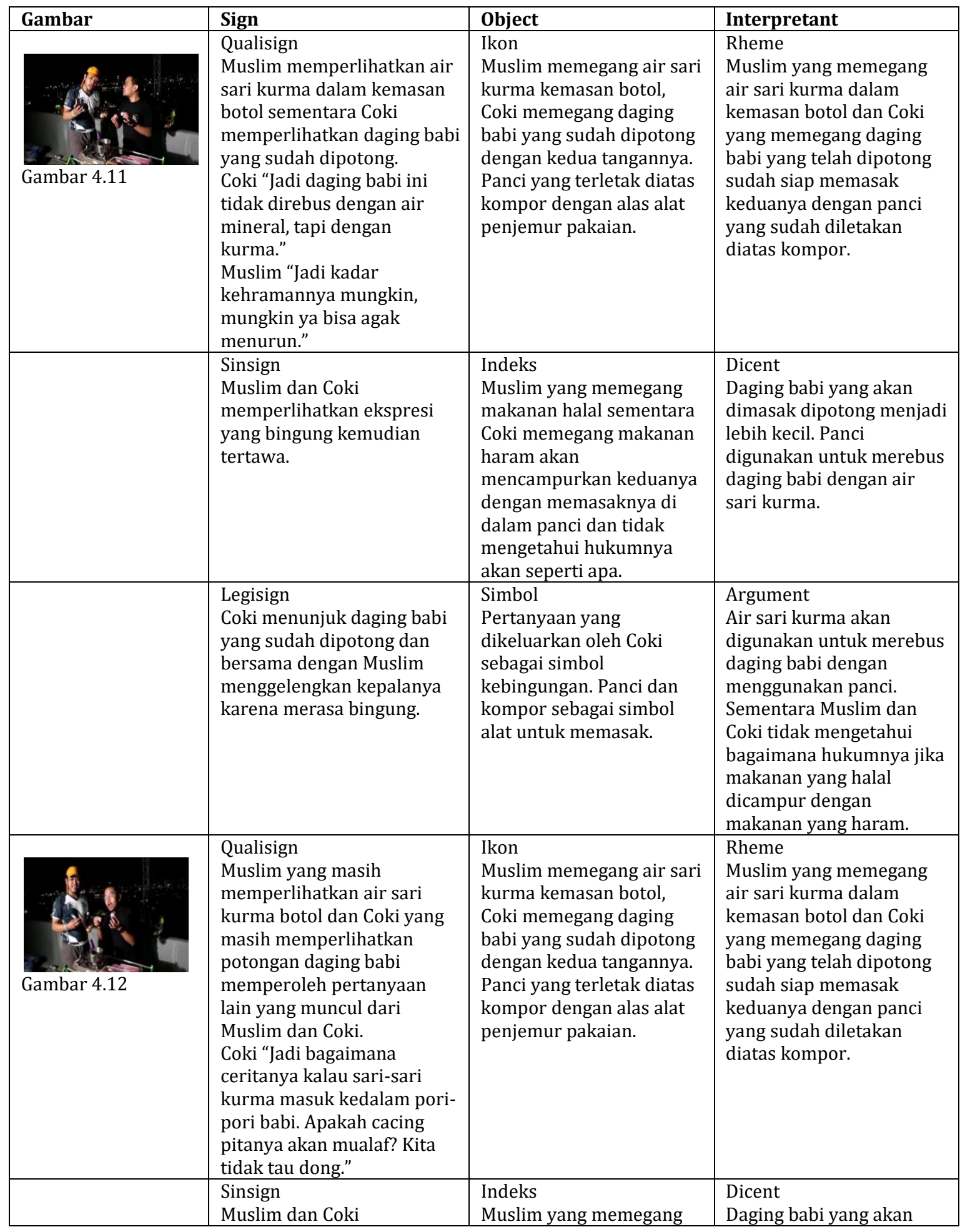




\begin{tabular}{|l|l|l|l|}
\hline & $\begin{array}{l}\text { memperlihatkan ekspresi } \\
\text { yang bingung kemudian } \\
\text { tertawa. }\end{array}$ & $\begin{array}{l}\text { makanan halal sementara } \\
\text { Coki memegang makanan } \\
\text { haram akan } \\
\text { mencampurkan keduanya } \\
\text { dengan memasaknya di } \\
\text { dalam panci dan tidak } \\
\text { mengetahui hukumnya } \\
\text { akan seperti apa. }\end{array}$ & $\begin{array}{l}\text { dimasak dipotong menjadi } \\
\text { lebih kecil. Panci } \\
\text { digunakan untuk merebus } \\
\text { daging babi dengan air } \\
\text { sari kurma. }\end{array}$ \\
\hline & $\begin{array}{l}\text { Legisign } \\
\text { Muslim menunjuk air sari } \\
\text { kurma dalam kemasan } \\
\text { botol, Coki menunjuk daging } \\
\text { babi yang telah dipotong } \\
\text { lalu keduanya } \\
\text { menggelengkan kepalanya } \\
\text { karena merasa bingung. }\end{array}$ & $\begin{array}{l}\text { Pertanyaan yang } \\
\text { dikeluarkan oleh Coki } \\
\text { sebagai simbol } \\
\text { kebingungan. Panci dan } \\
\text { kompor sebagai simbol } \\
\text { alat untuk memasak. }\end{array}$ & $\begin{array}{l}\text { Air sari kurma akan } \\
\text { digunakan untuk merebus } \\
\text { daging babi dengan } \\
\text { menggunakan panci. } \\
\text { Sementara Muslim dan } \\
\text { Coki tidak mengetahui } \\
\text { bagaimana hukumnya jika } \\
\text { makanan yang halal } \\
\text { dicampur dengan } \\
\text { makanan yang haram. }\end{array}$ \\
\hline
\end{tabular}

Tabel 5.Hasil analisis scene 5

\begin{tabular}{|c|c|c|c|}
\hline Gambar & Sign & Object & Interpretant \\
\hline \multirow[t]{3}{*}{ Gambar 4} & $\begin{array}{l}\text { Qualisign } \\
\text { Muslim dan Coki } \\
\text { memperlihatkan daging babi } \\
\text { dan air sari kurma yang } \\
\text { berada di dalam panci. } \\
\text { Coki "Ini kalau kita liat ini } \\
\text { kaya ada semacam resisten } \\
\text { gitu ya, semacam ada } \\
\text { perlawanan dari daging } \\
\text { babinya. Karena sepertinya } \\
\text { ada peperangan } \\
\text { antargolongan disini nih." }\end{array}$ & $\begin{array}{l}\text { Ikon } \\
\text { Daging babi dan air sari } \\
\text { kurma di dalam panci. } \\
\text { Terdapat juga pisau, } \\
\text { kompor dan alas yaitu alat } \\
\text { penjemur pakaian. }\end{array}$ & $\begin{array}{l}\text { Rheme } \\
\text { Daging babi yang sedang } \\
\text { direbus di dalam panci di } \\
\text { atas kompor dan diaduk } \\
\text { menggunakan pisau. }\end{array}$ \\
\hline & $\begin{array}{l}\text { Sinsign } \\
\text { Daging babi dan air sari } \\
\text { kurma yang direbus di } \\
\text { dalam panci. }\end{array}$ & $\begin{array}{l}\text { Indeks } \\
\text { Daging babi yang sedang } \\
\text { direbus dengan air sari } \\
\text { kurma menggunakan } \\
\text { panci dan diaduk } \\
\text { menggunakan pisau } \\
\text { terlihat tidak menyatu. }\end{array}$ & $\begin{array}{l}\text { Dicent } \\
\text { Daging babi sedang } \\
\text { dimasak dengan air sari } \\
\text { kurma yang digunakan } \\
\text { sebagai rebusan. Panci } \\
\text { digunakan untuk merebus } \\
\text { daging babi dan air sari } \\
\text { kurma. Sementara pisau } \\
\text { digunakan untuk } \\
\text { mengaduknya. }\end{array}$ \\
\hline & $\begin{array}{l}\text { Legisign } \\
\text { Panci digunakan untuk } \\
\text { memasak daging babi yang } \\
\text { direbus dengan air sari } \\
\text { kurma. }\end{array}$ & $\begin{array}{l}\text { Simbol } \\
\text { Panci dan kompor sebagai } \\
\text { alat masak. Daging babi } \\
\text { dan air sari kurma yang } \\
\text { diletakan di dalam panci } \\
\text { sebagai simbol sedang } \\
\text { dimasak. }\end{array}$ & $\begin{array}{l}\text { Argument } \\
\text { Daging babi yang dimasak } \\
\text { dengan cara direbus } \\
\text { menggunakan air sari } \\
\text { kurma tidak bisa menyatu } \\
\text { karena daging babi } \\
\text { merupakan makanan yang } \\
\text { haram bagi umat Islam } \\
\text { sementara air sari kurma }\end{array}$ \\
\hline
\end{tabular}




\begin{tabular}{|c|c|c|c|}
\hline & & & $\begin{array}{l}\text { merupakan makanan yang } \\
\text { halal. }\end{array}$ \\
\hline \multirow[t]{6}{*}{ Gambar 4.14} & $\begin{array}{l}\text { Qualisign } \\
\text { Muslim "Babi yang haramun, } \\
\text { al haramun, gak mau } \\
\text { kemasukan kurma, bro." } \\
\text { Coki “Iya kayanya ada } \\
\text { resisten. Nah sekarang } \\
\text { permasalahannya adalah } \\
\text { kalau kurma sama babi kita } \\
\text { satuin, yang babinya jadi gak } \\
\text { haram atau kurmanya yang } \\
\text { jadi haram?" } \\
\text { Muslim "Bener-bener, siapa } \\
\text { yang menang ya?" }\end{array}$ & $\begin{array}{l}\text { Ikon } \\
\text { Muslim yang melihat ke } \\
\text { arah masakan dan Coki } \\
\text { yang memegang pisau. }\end{array}$ & $\begin{array}{l}\text { Rheme } \\
\text { Muslim melihat proses } \\
\text { masak dari daging babi } \\
\text { dan air sari kurma. } \\
\text { Sementara Coki yang } \\
\text { selesai mengaduk } \\
\text { masakan melontarkan } \\
\text { pertanyaan. }\end{array}$ \\
\hline & $\begin{array}{l}\text { Sinsign } \\
\text { Muslim yang melihat ke arah } \\
\text { daging babi dan air sari } \\
\text { kurma yang sedang dimasak. } \\
\text { Coki menunjukkan ekspresi } \\
\text { yang bingung. }\end{array}$ & $\begin{array}{l}\text { Indeks } \\
\text { Muslim dan Coki sedang } \\
\text { berbicara mengenai } \\
\text { daging babi dan air sari } \\
\text { kurma yang sedang } \\
\text { dimasak. }\end{array}$ & $\begin{array}{l}\text { Dicent } \\
\text { Muslim melihat ke arah } \\
\text { masakan untuk } \\
\text { memastikan proses dari } \\
\text { masakan tersebut. } \\
\text { Sementara Coki bertanya } \\
\text { karena tidak tahu. }\end{array}$ \\
\hline & $\begin{array}{l}\text { Legisign } \\
\text { Coki mengaduk daging babi } \\
\text { dengan air sari kurma yang } \\
\text { sedang dimasak. }\end{array}$ & $\begin{array}{l}\text { Simbol } \\
\text { Ekspresi Muslim dan Coki } \\
\text { sebagai simbol } \\
\text { kebingungan. }\end{array}$ & $\begin{array}{l}\text { Argument } \\
\text { Karena proses memasak } \\
\text { yang mencampurkan } \\
\text { makanan haram dan halal, } \\
\text { Coki berpendapat bahwa } \\
\text { mungkin saja terjadi } \\
\text { percampuran zat haram } \\
\text { dan halalnya. }\end{array}$ \\
\hline & $\begin{array}{l}\text { Qualisign } \\
\text { Coki "Nah kalau air bekas ini } \\
\text { diminum, kurmanya jadi } \\
\text { haram gak? Nah kalau } \\
\text { babinya dimakan apakah } \\
\text { babinya jadi halal? Nah itu } \\
\text { kita gak tau, makanya biar } \\
\text { aman gua aja yang makan.” } \\
\text { Muslim "Kita tidak tau ya.” }\end{array}$ & $\begin{array}{l}\text { Ikon } \\
\text { Muslim yang melihat ke } \\
\text { arah masakan dan Coki } \\
\text { yang masih memegang } \\
\text { pisau melihat ke arah } \\
\text { Muslim. }\end{array}$ & $\begin{array}{l}\text { Rheme } \\
\text { Muslim yang masih } \\
\text { melihat proses memasak } \\
\text { tertawa ketika Coki } \\
\text { melontarkan pertanyaan } \\
\text { kepadanya. }\end{array}$ \\
\hline & $\begin{array}{l}\text { Sinsign } \\
\text { Muslim memperlihatkan } \\
\text { ekspresi tertawa. Sementara } \\
\text { Coki masih bingung. }\end{array}$ & $\begin{array}{l}\text { Indeks } \\
\text { Muslim dan Coki sedang } \\
\text { berbicara mengenai } \\
\text { daging babi dan air sari } \\
\text { kurma yang sedang } \\
\text { dimasak. }\end{array}$ & $\begin{array}{l}\text { Dicent } \\
\text { Muslim melihat ke arah } \\
\text { masakan untuk } \\
\text { memastikan proses dari } \\
\text { masakan tersebut. } \\
\text { Sementara Coki yang } \\
\text { masih tidak tahu bertanya } \\
\text { lagi dan membuat Muslim } \\
\text { tertawa. }\end{array}$ \\
\hline & $\begin{array}{l}\text { Legisign } \\
\text { Coki menunjuk daging babi } \\
\text { yang sedang dimasak } \\
\text { dengan air sari kurma di } \\
\text { dalam panci. Sementara } \\
\text { Muslim melihat kearah } \\
\text { masakan tersebut. }\end{array}$ & $\begin{array}{l}\text { Simbol } \\
\text { Coki melihat ke arah } \\
\text { Muslim sebagai simbol } \\
\text { sedang mengajak } \\
\text { berbicara. Ekspresi } \\
\text { tertawa Muslim sebagai } \\
\text { simbol rasa senang. }\end{array}$ & $\begin{array}{l}\text { Argument } \\
\text { Selain itu, Coki juga } \\
\text { berpendapat mungkin saja } \\
\text { bisa terjadi pertukaran zar } \\
\text { haram dan halal dari } \\
\text { kedua bahan makanan } \\
\text { tersebut. }\end{array}$ \\
\hline
\end{tabular}


Tabel 6. Hasil analisis scene 6.

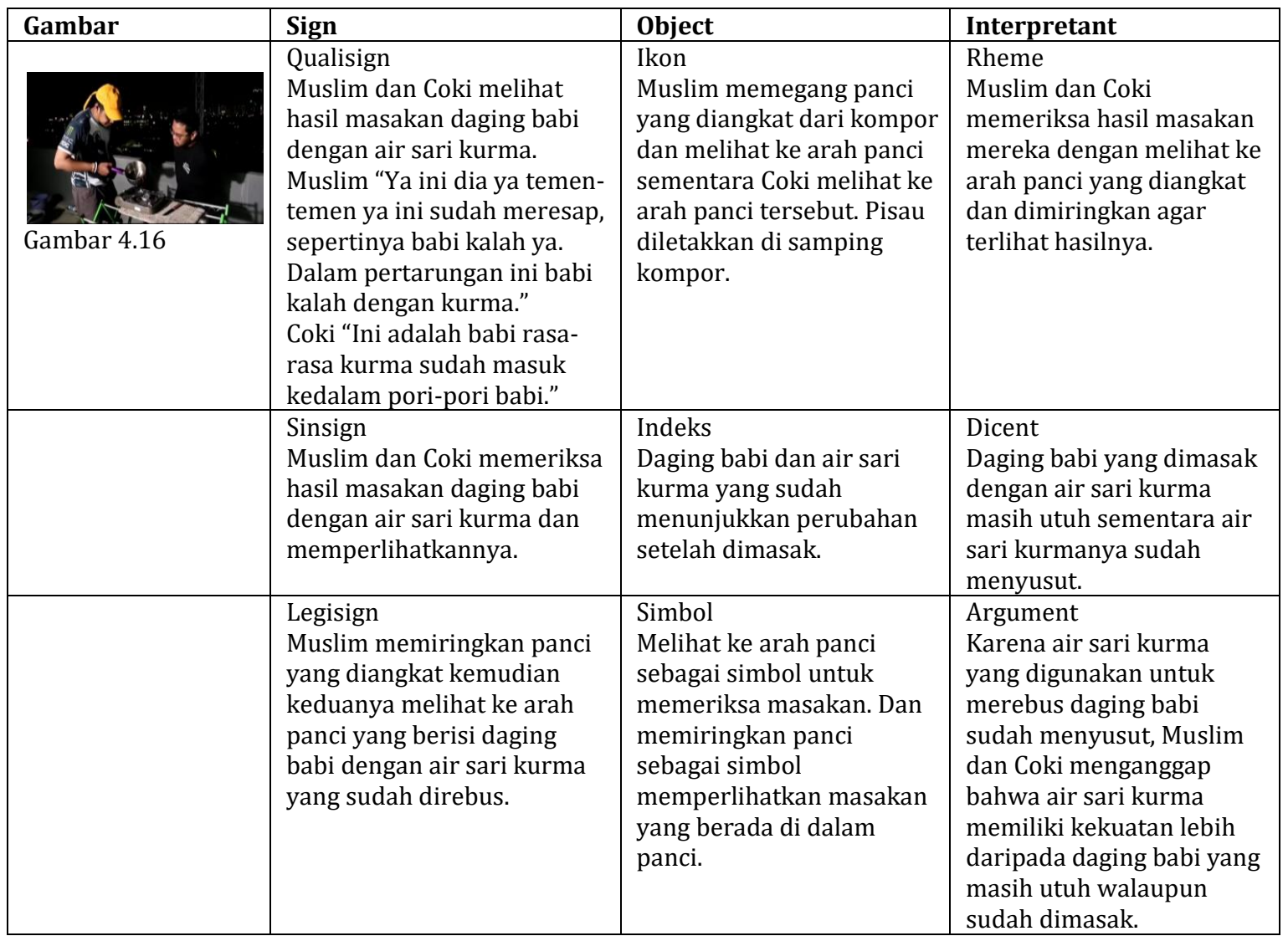

Tabel 7. Hasil analisis scene 8.

\begin{tabular}{|l|l|l|l|}
\hline Gambar & Sign & Object & Interpretant \\
\hline $\begin{array}{l}\text { Qualisign } \\
\text { Muslim "Ini makanan khas } \\
\text { Anda, al babi, makanan khas } \\
\text { Anda, bro." }\end{array}$ & $\begin{array}{l}\text { Ikon } \\
\text { Muslim yang melihat ke } \\
\text { arah Coki. Sementara Coki } \\
\text { sedang mengaduk } \\
\text { masakan. }\end{array}$ & $\begin{array}{l}\text { Rheme } \\
\text { Muslim menunjuk Coki } \\
\text { yang sedang mengaduk } \\
\text { masakan dan } \\
\text { mengajaknya berbicara } \\
\text { dengan serius sementara } \\
\text { Coki tertawa. }\end{array}$ \\
\hline & $\begin{array}{l}\text { Sinsign } \\
\text { Muslim menunjukkan } \\
\text { ekspresi serius sementara } \\
\text { Coki tertawa. }\end{array}$ & $\begin{array}{l}\text { Muslim berbicara kepada } \\
\text { Coki. }\end{array}$ & $\begin{array}{l}\text { Dicent } \\
\text { Coki adalah orang yang } \\
\text { beragama non Islam yang } \\
\text { sering memakan daging } \\
\text { babi. }\end{array}$ \\
\hline & $\begin{array}{l}\text { Legisign } \\
\text { Muslim menunjuk Coki. }\end{array}$ & $\begin{array}{l}\text { Simbol } \\
\text { Muslim menunjuk Coki } \\
\text { sebagai simbol } \\
\text { memberitahu. }\end{array}$ & $\begin{array}{l}\text { Daging babi adalah } \\
\text { makanan yang sering } \\
\text { dimakan oleh orang } \\
\text { beragama non Islam tetapi }\end{array}$ \\
\hline
\end{tabular}




\begin{tabular}{|c|c|c|c|}
\hline & & & $\begin{array}{l}\text { haram hukumnya bagi } \\
\text { orang Islam sehingga } \\
\text { daging babi hanya } \\
\text { dimakan oleh orang } \\
\text { beragama selain Islam. }\end{array}$ \\
\hline Gambar 4.18 & $\begin{array}{l}\text { Qualisign } \\
\text { Muslim masih melihat ke } \\
\text { arah Coki. } \\
\text { Muslim "Kenapa? Kan babi } \\
\text { ya kan dimasak oriental, } \\
\text { gulai oriental. Kan ini udah } \\
\text { oriental banget bro. Oh } \\
\text { kurang satu kalau mau } \\
\text { oriental...” }\end{array}$ & $\begin{array}{l}\text { Ikon } \\
\text { Muslim menggunakan } \\
\text { mengubah bentuk } \\
\text { matanya menggunakan } \\
\text { tangan untuk } \\
\text { memperlihatkan sesuatu } \\
\text { kepada Coki. Lalu Coki } \\
\text { menoleh ke arah lain } \\
\text { sambil tertawa. }\end{array}$ & $\begin{array}{l}\text { Rheme } \\
\text { Muslim menirukan orang } \\
\text { China dengan menyipitkan } \\
\text { matanya dan } \\
\text { mengarahkannya kepada } \\
\text { Coki sehingga membuat } \\
\text { Coki tertawa. }\end{array}$ \\
\hline & $\begin{array}{l}\text { Sinsign } \\
\text { Muslim dan Coki tertawa. }\end{array}$ & $\begin{array}{l}\text { Indeks } \\
\text { Muslim menunjukkan } \\
\text { sesuatu kepada Coki yang } \\
\text { membuat Coki tertawa. }\end{array}$ & $\begin{array}{l}\text { Dicent } \\
\text { Muslim menirukan orang } \\
\text { China dengan membuat } \\
\text { matanya menjadi lebih } \\
\text { sipit. }\end{array}$ \\
\hline & $\begin{array}{l}\text { Legisign } \\
\text { Muslim membuat gerakan } \\
\text { dengan seolah-olah } \\
\text { membuat matanya sipit } \\
\text { dengan menggunakan } \\
\text { tangannya dan } \\
\text { mengarahkannya kepada } \\
\text { Coki. }\end{array}$ & $\begin{array}{l}\text { Simbol } \\
\text { Muslim menggunakan } \\
\text { tangannya sebagai simbol } \\
\text { menyipitkan mata. Mata } \\
\text { yang sipit adalah simbol } \\
\text { dari orang China. }\end{array}$ & $\begin{array}{l}\text { Argument } \\
\text { Oriental berkaitan dengan } \\
\text { masakan China dan orang } \\
\text { China memiliki ciri khas } \\
\text { fisik yaitu matanya yang } \\
\text { sipit dan sering dijadikan } \\
\text { minoritas. }\end{array}$ \\
\hline
\end{tabular}

Tabel 8. Hasil analisis scene 9.

\begin{tabular}{|l|l|l|l|}
\hline Gambar & Sign & Object & Interpretant \\
\hline & $\begin{array}{l}\text { Qualisign } \\
\text { Muslim terkena cipratan dan } \\
\text { berbicara kepada Coki yang } \\
\text { sedang mengaduk masakan. } \\
\text { Muslim "Emang babi kalau } \\
\text { dimasak orang Islam, pasti } \\
\text { ada perlawanan, bro." }\end{array}$ & $\begin{array}{l}\text { Ikon } \\
\text { Muslim yang sedang } \\
\text { berbicara, Coki yang } \\
\text { sedang tertawa, daging } \\
\text { babi dan air sari kurma } \\
\text { yang sedang dimasak } \\
\text { menggunakan panci, pisau } \\
\text { yang dipegang Coki, alat } \\
\text { penjemur pakaian sebagai } \\
\text { alasnya. }\end{array}$ & $\begin{array}{l}\text { Rheme } \\
\text { Muslim yang terkena } \\
\text { cipratan dari masakan } \\
\text { daging babi dengan air sari } \\
\text { kurma sambil menunjuk } \\
\text { ke masakannya, berbicara } \\
\text { kepada Coki dengan } \\
\text { benada kesal. Sementara } \\
\text { Coki yang sedang } \\
\text { mengaduk tidak terkena } \\
\text { cipratan dan tertawa } \\
\text { menanggapi perkataan } \\
\text { Muslim. }\end{array}$ \\
& $\begin{array}{l}\text { Sinsign } \\
\text { Muslim menunjukkan } \\
\text { ekspresi yang serius ketika } \\
\text { berbicara sementara Coki } \\
\text { tertawa. }\end{array}$ & $\begin{array}{l}\text { Muslim yang terkena } \\
\text { cipratan masakan daging } \\
\text { babi dengan air sari kurma } \\
\text { merasa kesal dan } \\
\text { membuat Coki tertawa. }\end{array}$ & $\begin{array}{l}\text { Dicent } \\
\text { Muslim yang menunjuk } \\
\text { daging babi dan air sari } \\
\text { kurma yang sedang } \\
\text { dimasak dengan jarak } \\
\text { agak jauh dan Coki yang } \\
\text { juga menjauhkan } \\
\text { tangannya karena } \\
\text { masakan tersebut } \\
\text { menimbulkan cipratan }\end{array}$ \\
\hline
\end{tabular}




\begin{tabular}{|c|c|c|c|}
\hline & & & $\begin{array}{l}\text { yang bisa mengenai } \\
\text { keduanya. }\end{array}$ \\
\hline & $\begin{array}{l}\text { Legisign } \\
\text { Muslim menunjuk daging } \\
\text { babi dan air sari kurma yang } \\
\text { sedang dimasak dengan } \\
\text { jarak agak jauh dari kompor } \\
\text { karena terkena cipratan. } \\
\text { Sementara Coki mengaduk } \\
\text { masakan menggunakan } \\
\text { pisau tetapi tangan kirinya } \\
\text { diangkat jauh dari kompor } \\
\text { agar tidak terkena cipratan. }\end{array}$ & $\begin{array}{l}\text { Simbol } \\
\text { Muslim menunjuk ke } \\
\text { daging babi dan air sari } \\
\text { kurma yang sedang } \\
\text { dimasak sebagai simbol } \\
\text { ingin memperlihatkan. } \\
\text { Sementara Coki yang } \\
\text { menjauhkan tangannya } \\
\text { dari masakan sebagai } \\
\text { simbol ketakutan atau } \\
\text { waspada. Raut wajah Coki } \\
\text { yang tertawa sebagai } \\
\text { simbol kesenangan. }\end{array}$ & $\begin{array}{l}\text { Argument } \\
\text { Karena daging babi } \\
\text { merupakan makanan yang } \\
\text { haram bagi umat Islam } \\
\text { maka cipratan dari } \\
\text { masakannya mengenai } \\
\text { Muslim. Sementara tidak } \\
\text { mengenai Coki karena dia } \\
\text { adalah orang yang } \\
\text { beragama non Islam. }\end{array}$ \\
\hline \multirow[t]{4}{*}{ Gambar 4.20} & $\begin{array}{l}\text { Qualisign } \\
\text { Muslim berbicara kepada } \\
\text { Coki yang sedang mengaduk } \\
\text { masakan. } \\
\text { Muslim "Babi kalau disentuh } \\
\text { tangan orang Islam, yang } \\
\text { dicipratin nih pasti ngarah- } \\
\text { ngarah kesini. }\end{array}$ & $\begin{array}{l}\text { Ikon } \\
\text { Muslim yang sedang } \\
\text { berbicara, Coki yang } \\
\text { sedang tertawa, daging } \\
\text { babi dan air sari kurma } \\
\text { yang sedang dimasak di } \\
\text { dalam panci, pisau yang } \\
\text { dipegang Coki, alat } \\
\text { penjemur pakaian sebagai } \\
\text { alasnya. }\end{array}$ & $\begin{array}{l}\text { Rheme } \\
\text { Muslim yang terkena } \\
\text { cipratan dari masakan } \\
\text { daging babi dengan air sari } \\
\text { kurma sambil menunjuk } \\
\text { ke masakannya, berbicara } \\
\text { kepada Coki dengan } \\
\text { benada kesal. Sementara } \\
\text { Coki yang sedang } \\
\text { mengaduk tidak terkena } \\
\text { cipratan dan tertawa } \\
\text { menanggapi perkataan } \\
\text { Muslim. }\end{array}$ \\
\hline & $\begin{array}{l}\text { Sinsign } \\
\text { Muslim menunjukkan } \\
\text { ekspresi yang serius ketika } \\
\text { berbicara sementara Coki } \\
\text { tertawa. }\end{array}$ & $\begin{array}{l}\text { Indeks } \\
\text { Muslim yang terkena } \\
\text { cipratan masakan daging } \\
\text { babi dengan air sari kurma } \\
\text { merasa kesal dan } \\
\text { membuat Coki tertawa. }\end{array}$ & $\begin{array}{l}\text { Dicent } \\
\text { Muslim yang menunjuk } \\
\text { daging babi dan air sari } \\
\text { kurma yang sedang } \\
\text { dimasak dengan jarak } \\
\text { agak jauh dan Coki yang } \\
\text { juga menjauhkan } \\
\text { tangannya karena } \\
\text { masakan tersebut } \\
\text { menimbulkan cipratan } \\
\text { yang bisa mengenai } \\
\text { keduanya. }\end{array}$ \\
\hline & $\begin{array}{l}\text { Legisign } \\
\text { Muslim menunjuk daging } \\
\text { babi dan air sari kurma yang } \\
\text { sedang dimasak dengan } \\
\text { jarak agak jauh dari kompor } \\
\text { karena terkena cipratan. } \\
\text { Sementara Coki mengaduk } \\
\text { masakan menggunakan } \\
\text { pisau tetapi tangan kirinya } \\
\text { diangkat jauh dari kompor } \\
\text { agar tidak terkena cipratan. }\end{array}$ & $\begin{array}{l}\text { Simbol } \\
\text { Muslim menunjuk ke } \\
\text { daging babi dan air sari } \\
\text { kurma yang sedang } \\
\text { dimasak sebagai simbol } \\
\text { ingin memperlihatkan. } \\
\text { Sementara Coki yang } \\
\text { menjauhkan tangannya } \\
\text { dari masakan sebagai } \\
\text { simbol ketakutan atau } \\
\text { kewaspadaan. Raut wajah } \\
\text { Muslim yang serius juga } \\
\text { sebagai simbol kekesalan. }\end{array}$ & $\begin{array}{l}\text { Argument } \\
\text { Karena daging babi } \\
\text { merupakan makanan yang } \\
\text { haram bagi umat Islam } \\
\text { maka cipratan dari } \\
\text { masakannya mengenai } \\
\text { Muslim. Sementara tidak } \\
\text { mengenai Coki karena dia } \\
\text { adalah orang yang } \\
\text { beragama non Islam. }\end{array}$ \\
\hline & $\begin{array}{l}\text { Qualisign } \\
\text { Muslim menggerakkan }\end{array}$ & $\begin{array}{l}\text { Ikon } \\
\text { Muslim menggerakkan }\end{array}$ & $\begin{array}{l}\text { Rheme } \\
\text { Muslim menunjukan }\end{array}$ \\
\hline
\end{tabular}




\begin{tabular}{|c|c|c|c|}
\hline Gambar 4.21 & $\begin{array}{l}\text { tangannya. } \\
\text { Muslim “Jangan masak saya! } \\
\text { Jangan masak saya! }\end{array}$ & $\begin{array}{l}\text { tangannya, Coki yang } \\
\text { sedang tertawa, daging } \\
\text { babi dan air sari kurma } \\
\text { yang sedang dimasak di } \\
\text { dalam panci, pisau yang } \\
\text { dipegang Coki, alat } \\
\text { penjemur pakaian sebagai } \\
\text { alasnya. }\end{array}$ & $\begin{array}{l}\text { gerakan tangannya keatas } \\
\text { seolah-olah menjadi } \\
\text { daging babi yang sedang } \\
\text { memberontak dan tidak } \\
\text { ingin dimasak oleh dirinya } \\
\text { karena selalu } \\
\text { mengeluarkan cipratan. } \\
\text { Sementara Coki masih } \\
\text { tertawa menanggapi } \\
\text { gerakan Muslim. }\end{array}$ \\
\hline & $\begin{array}{l}\text { Sinsign } \\
\text { Muslim menunjukkan } \\
\text { ekspresi yang kesal saat } \\
\text { menggerakkan tangannya } \\
\text { sementara Coki tertawa. }\end{array}$ & $\begin{array}{l}\text { Indeks } \\
\text { Muslim membuat gerakan } \\
\text { seperti seolah-olah daging } \\
\text { babi memberontak dan } \\
\text { tidak ingin dimasak oleh } \\
\text { Muslim. }\end{array}$ & $\begin{array}{l}\text { Dicent } \\
\text { Muslim menggambarkan } \\
\text { daging babi yang } \\
\text { memberontak karena } \\
\text { tidak ingin dimasak dan } \\
\text { menimbulkan cipratan. }\end{array}$ \\
\hline & $\begin{array}{l}\text { Legisign } \\
\text { Muslim menggerakkan } \\
\text { tangannya ke arah atas. }\end{array}$ & $\begin{array}{l}\text { Simbol } \\
\text { Muslim menggerakkan } \\
\text { tangannya sebagai simbol } \\
\text { dari pemberontakan } \\
\text { daging babi yang tidak } \\
\text { ingin dimasak. }\end{array}$ & $\begin{array}{l}\text { Argument } \\
\text { Karena Muslim adalah } \\
\text { orang beragama Islam } \\
\text { maka dia berpendapat } \\
\text { bahwa daging babi } \\
\text { menolak jika dimasak oleh } \\
\text { dirinya sehingga seperti } \\
\text { memberontak. }\end{array}$ \\
\hline Gambar 4.22 & $\begin{array}{l}\text { Qualisign } \\
\text { Coki “Aduh!” } \\
\text { Muslim “Nah itu kalau itu } \\
\text { kurma. Kurma tidak mau } \\
\text { dimasak orang kafir.” }\end{array}$ & $\begin{array}{l}\text { Ikon } \\
\text { Muslim yang menunjuk } \\
\text { Coki, Coki memegang } \\
\text { tangannya, pisau yang } \\
\text { dipegang Coki. }\end{array}$ & $\begin{array}{l}\text { Rheme } \\
\text { Akhirnya Coki juga } \\
\text { terkena cipratan dari } \\
\text { masakan daging babi } \\
\text { dengan air sari kurma dan } \\
\text { membersihkan tangannya. } \\
\text { Kemudian Muslim yang } \\
\text { melihatnya tertawa karena } \\
\text { bukan hanya dirinya saja } \\
\text { yang terkena. }\end{array}$ \\
\hline & $\begin{array}{l}\text { Sinsign } \\
\text { Muslim menunjukkan } \\
\text { ekspresi tertawa saat } \\
\text { melihat ke arah Coki } \\
\text { sementara Coki terlihat } \\
\text { kesal karena terkena } \\
\text { cipratan masakan. }\end{array}$ & $\begin{array}{l}\text { Indeks } \\
\text { Coki yang juga terkena } \\
\text { cipratan masakan daging } \\
\text { babi dengan air sari kurma } \\
\text { merasa kesal. Lalu Muslim } \\
\text { memperingatkannya } \\
\text { karena sebelumnya terjadi } \\
\text { juga kepada dirinya. }\end{array}$ & $\begin{array}{l}\text { Dicent } \\
\text { Coki yang sedang } \\
\text { mengaduk masakan } \\
\text { terkena cipratan dan } \\
\text { membersihkannya dengan } \\
\text { membasuh tangannya } \\
\text { sendiri. }\end{array}$ \\
\hline & $\begin{array}{l}\text { Legisign } \\
\text { Muslim menunjuk Coki } \\
\text { sementara Coki menyentuh } \\
\text { dan membasuh tangannya } \\
\text { yang sedang mengaduk } \\
\text { masakan karena terkena } \\
\text { cipratan. }\end{array}$ & $\begin{array}{l}\text { Simbol } \\
\text { Muslim menunjuk Coki } \\
\text { sebagai simbol } \\
\text { memperlihatkan. } \\
\text { Sementara Coki } \\
\text { menyentuh dan } \\
\text { membasuh tangannya } \\
\text { sebagai simbol } \\
\text { membersihkan cipratan } \\
\text { dari masakan. Raut wajah } \\
\text { Coki sebagai simbol } \\
\text { kekesalan. }\end{array}$ & $\begin{array}{l}\text { Argument } \\
\text { Ternyata tidak hanya } \\
\text { Muslim yang terkena } \\
\text { cipratan tetapi Coki juga. } \\
\text { Muslim menganggap } \\
\text { bahwa Coki juga tidak bisa } \\
\text { memasak daging babi } \\
\text { padahal dia sering } \\
\text { memakannya. }\end{array}$ \\
\hline & Qualisign & Ikon & Rheme \\
\hline
\end{tabular}




\begin{tabular}{|c|c|c|c|}
\hline Gambar 4.23 & $\begin{array}{l}\text { Muslim menggerakkan } \\
\text { tangannya. } \\
\text { Coki "Ini kan dibelakang situ } \\
\text { ada toren air, nanti untuk } \\
\text { membuat kostan ini heboh, } \\
\text { air tumisan babi akan kita } \\
\text { campur ke toren air kostan. } \\
\text { Besok pagi semua orang } \\
\text { kostan mandi kaldu babi." } \\
\text { Muslim "Kenapa air neraka." }\end{array}$ & $\begin{array}{l}\text { Muslim menggerakkan } \\
\text { tangannya, Coki tertawa, } \\
\text { pisau yang dipegang Coki. }\end{array}$ & $\begin{array}{l}\text { Muslim menggerakkan } \\
\text { tangannya karena ingin } \\
\text { menunjukkan bahwa } \\
\text { cipratan air tersebut } \\
\text { mengenai tubuhnya. }\end{array}$ \\
\hline & $\begin{array}{l}\text { Sinsign } \\
\text { Muslim dan Coki } \\
\text { menunjukkan ekspresi } \\
\text { tertawa. }\end{array}$ & $\begin{array}{l}\text { Indeks } \\
\text { Cipratan air dari masakan } \\
\text { daging babi dengan air sari } \\
\text { kurma mengenai tubuh } \\
\text { Muslim dan Coki. }\end{array}$ & $\begin{array}{l}\text { Dicent } \\
\text { Muslim menggambarkan } \\
\text { cipratan dari masakan } \\
\text { tersebut yang mengenai } \\
\text { tubuhnya. }\end{array}$ \\
\hline & $\begin{array}{l}\text { Legisign } \\
\text { Muslim menggerakkan } \\
\text { tangannya ke arah tubuh } \\
\text { seperti sedang membasuh. } \\
\text { Coki menjauhkan tangannya } \\
\text { dari kompor agar tidak } \\
\text { terkena cipratan. }\end{array}$ & $\begin{array}{l}\text { Simbol } \\
\text { Muslim menggerakkan } \\
\text { tangan ke tubuhnya } \\
\text { sebagai simbol cipratan air } \\
\text { yang mengenainya. Raut } \\
\text { wajah Muslim dan Coki } \\
\text { sebagai simbol } \\
\text { kesenangan. Sementara } \\
\text { Coki menjauhkan } \\
\text { tangannya sebagai simbol } \\
\text { ketakutan atau } \\
\text { kewaspadaan. }\end{array}$ & $\begin{array}{l}\text { Argument } \\
\text { Cipratan yang mengenai } \\
\text { tubuh Muslim adalah air } \\
\text { sari kurma yang dipakai } \\
\text { untuk merebus daging } \\
\text { babi dan dinilai sudah } \\
\text { menjadi makanan yang } \\
\text { haram. }\end{array}$ \\
\hline
\end{tabular}

Tabel 9. Hasil analisis scene 10.

\begin{tabular}{|l|l|l|l|}
\hline Gambar & Sign & Object & Interpretant \\
\hline & $\begin{array}{l}\text { Qualisign } \\
\text { Muslim “Nah ente kan suka } \\
\text { dessert biasanya. Makanya } \\
\text { ini kan abis makan babi itu } \\
\text { kan penuh dengan dosa. } \\
\text { Penuh dengan al haram, al } \\
\text { mudarat, kita cuci pakai } \\
\text { dessert, bro." }\end{array}$ & $\begin{array}{l}\text { Ikon } \\
\text { puslim yang memegang } \\
\text { dan Coki yang melihat ke } \\
\text { arah Muslim. }\end{array}$ & $\begin{array}{l}\text { Rheme } \\
\text { Muslim sedang berbicara } \\
\text { kepada penonton tetapi } \\
\text { Coki juga ikut } \\
\text { memperhatikan. }\end{array}$ \\
\hline $\begin{array}{l}\text { Sinsign } \\
\text { Ekspresi yang ditunjukkan } \\
\text { Muslim saat berbicara } \\
\text { sangat serius. }\end{array}$ & $\begin{array}{l}\text { Indeks } \\
\text { Muslim memberikan } \\
\text { peringatan bahwa jika } \\
\text { memakan makanan haram } \\
\text { yaitu daging babi akan } \\
\text { berdosa bagi umat Islam. }\end{array}$ & $\begin{array}{l}\text { Muslim menjelaskan } \\
\text { bahwa jika memakan } \\
\text { daging babi haram } \\
\text { hukumnya dan akan } \\
\text { berdosa bagi umat Islam. }\end{array}$ \\
\hline & $\begin{array}{l}\text { Legisign } \\
\text { Muslim menggerakan } \\
\text { tangannya dan Coki melihat } \\
\text { ke arah Muslim. }\end{array}$ & $\begin{array}{l}\text { Muslim menggerakkan } \\
\text { tangannya sebagai simbol } \\
\text { memberi tahu. Coki } \\
\text { melihat ke arah Muslim } \\
\text { sebagai simbol sedang } \\
\text { mendengarkan lawan } \\
\text { bicaranya. }\end{array}$ & $\begin{array}{l}\text { Argument } \\
\text { Karena daging babi adalah } \\
\text { makanan yang } \\
\text { diharamkan oleh umat } \\
\text { Islam, maka orang yang } \\
\text { memakannya sudah pasti } \\
\text { akan memiliki banyak } \\
\text { dosa. }\end{array}$ \\
\hline
\end{tabular}




\section{PERSERPSI}

Volume 2/Nomor1

Juli - Desember 2019

E-ISSN 2656-050X

Hasil penelitian menunjukkan bahwa video Last Hope Kitchen episode Puding Babi Kurma mengandung unsur SARA yang dapat dijelaskan sebagai berikut:

\section{Unsur Suku}

Pada saat proses memasak daging babi dan air sari kurma, Muslim menunjukkan gerakan menyipitkan mata dengan kedua tangannya dan berkata Pada saat proses memasak daging babi dan air sari kurma, Muslim berkata "Kenapa? Kan babi ya kan dimasak oriental, gulai oriental. Kan ini udah oriental banget bro. Oh kurang satu kalau mau oriental..."dan langsung menunjukkan gerakan menyipitkan mata dengan kedua tangannya. Hal tersebut secara langsung menyinggung suku dan etnis Tionghoa yang kebanyakan memiliki ciri fisik mata yang sipit. Walaupun tidak disebutkan secara terang-terangan tetapi para penonton pasti mengetahui bahwa gerakan Muslim tersebut menggambarkan etnis Tionghoa.

\section{Unsur Agama}

Makanan haram dan makanan yang halal dalam agama Islam termasuk sesuatu yang berhubungan dengan kesucian. Karena hal tersebut salah satunya merupakan sesuatu yang harus dihindari dan dilarang dalam agama Islam. Sehingga bagi umat Islam, memakan daging babi adalah haram hukumnya sesuai dengan firma Allah dan hadits Nabi yang sudah dijelaskan. Selain itu, hukum haram dan halal dianggap sebagai sesuatu yang suci dan dihormati karena merupakan suatu sistem keyakinan yaitu agama Islam yang melarang umatnya mengkonsumsi makanan yang haram.

Selain sesuatu yang sakral atau suci, menurut Durkheim agama memiliki sesuatu yang profan atau dianggap biasa yang merupakan refleksi dari kehidupan sehari-hari dan bersifat biasa-biasa saja. Dalam video ini, sesuatu yang profan dapat terlihat dari Coki yang menggunakan kaos berwarna hitam dengan tulisan "Anti Religion-Religion Club" yang dapat memunculkan banyak persepsi yang berbeda dari penontonnya. Seperti yang sudah banyak orang ketahui, Coki merupakan seorang beragama non Islam. Coki menggunakan kaos tersebut sebagai parodi dari "Anti Social-Social Club" yang merupakan brand ternama dari Amerika. 


\section{PERSERPSI}

Volume 2/Nomor1

Juli - Desember 2019

E-ISSN 2656-050X

\section{Unsur Antargolongan}

Ketika memperlihatkan daging babi yang mulai dimasak dengan air sari kurma, Muslim dan Coki menyebutkan bahwa terjadi perang antargolongan. Sementara seperti yang diketahui banyak orang, antargolongan adalah sekelompok orang yang memiliki kesadaran bersama dan saling berinteraksi. Bukan benda mati atau makanan seperti daging babi dan air sari kurma.

Media yang digunakan oleh Muslim adalah media sosial yaitu YouTube yang memiliki asas kebebasan bagi para pembuat video di YouTube. Mereka bebas menyampaikan pendapat dan kreativitas mereka dalam video tetapi YouTube juga memiliki ketentuan mengenai konten.

Kontroversi lainnya adalah penonton yang merasa tersinggung kebanyakan berasal dari agama mayoritas. Dimana mereka mengungkapkan rasa kesalnya melalui kolom komentar dari video tersebut. Bahkan menulisnya di media sosial lainnya seperti twitter dan instagram. Hal tersebut merupakan diskursus yang terjadi dimana para penonton saling mengungkapkan komentarnya setelah melihat video tersebut.

\section{Simpulan}

Unsur SARA yang menjadi kontroversi adalah suku, agama, dan antargolongan. Muslim menunjukkan gerakan menirukan suku dan ras China dengan menyipitkan kedua matanya menggunakan tangan seolah-olah menjadi seperti orang China yang ditunjukkan dalam bentuk gesture pada gambar 4.18 scene 8 .

Unsur agama ditunjukkan Muslim dan Coki dengangesture dan percakapan yang seolah-olah mejadikan agama yang merupakan sesuatu yang suci dan dihormati sebagai bahan bercandaan. Hampir pada seluruh gambar dan scene menjadi kesatuan alur cerita.

Unsur antargolongan, Muslim dan Coki menganggap bahwa jika daging babi dan air sari kurma dicampur dan dimasak maka akan terjadi kondisi seperti peperangan antargolongan yang ditunjukkan dalam bentuk percakapan pada gambar 4.13 scene 5 . 


\section{PERSEPSI}

Volume 2/Nomor1

Juli - Desember 2019

E-ISSN 2656-050X

\section{REFERENSI}

Durkheim, E. (2003). Sejarah Agama. Yogyakarta: Ircisod.

Fatwa Majelis Ulama Indonesia Tentang Hukum Hewan Ternak yang Diberi Pakan dari Barang Najis. (2012). Komisi Fatwa Majelis Ulama Indonesia, 3-4.

Ghafur, A. (2016). Critical Discourse Analysis Sebuah Model Analisis Sosial Kritis dalam Teks Media. OKARA Journal of Languages and Literature, Vol.02 No.10, 180.

Hardiman, F. B. (2009). Demokrasi Deliberatif. Yogyakarta: Kanisius.

Kholifah, S. (2014). Analisis Semiotika Pesan Sosial dalam Video "Takotak Miskumis" di YouTube. e-Jurnal Ilmu Komunikasi, Vol.2 No.03, 138.

Leonardy, W. (2016). Penegakan Hukum Terhadap Pelaku Tindak Pidana Penistaan Suku, Agama, Ras, dan Antargolongan Melalui Media Elektronik atau Jejarin Sosial. JOM Fakultas Hukum Vol. 03 No. 02, 8.

McQuail, D. (2012). Teori Komunikasi Massa. Jakarta: Salemba Humanika.

Mutma, F. S. (2017). Pemaknaan Followers terhadap Gaya Hidup Selebgram (Studi Resepsi pada Viewers Vlog Akun Youtube Karin Novilda). Prosiding Konferensi Nasional Komunikasi, Vol.01 No.01, 152-165.

Rulli, N. (2014). Teori dan Riset Media Siber. Jakarta: Kencana Prenada Media Group.

Sobur, A. (2013). Semiotika Komunikasi. Bandung: Remaja Rosdakarya Offset.

About Policies \#Reporting and Enforcement. (2018). Youtube.com: https://www.youtube.com/intl/id/yt/about/policies/\#reporting-and-enforcement.

Diakses pada tanggal 7 November 2018

Putri, A. W. (2018, October 24). Tayangan Youtube Babi-Kurma dan Genre Dark Comedy yang "Provokatif". Tirto.id: https://www.google.co.id/amp/s/amp.tirto.id/tayangan-youtube-babi-kurmadan-genre-dark-comedy-yang-provokatif-c8ra. Diakses pada tanggal 31 Oktober 2018

Sun, S. (2017, December 30). 6 Dasar dalam Membuat Konten Channel Youtube-mu. Wehype.id: https://wehype.id/index.php/2017/12/30/6-dasar-dalammembuat-konten-channel-youtube-mu. Diakses pada tanggal 9 November 2018 